DOI https://doi.org/10.36059/978-966-397-121-6/277-294

\title{
CONSEPTUAL COMPETENCY MODEL OF LEADER (BY THE EXAMPLE OF NATIONAL POLICE OF UKRAINE AGENCIES)
}

\section{Tsilmak O. M.}

\section{INTRODUCTION}

Law-enforcement activity sets high requirements for the level of professionalism and professional workmanship of policemen. In leading documents of Ministry of internal affairs of Ukraine and National police, - incompetence is considered as unprofessionalism, the consequence of which is an increase of quantity of undiscovered criminal offences, the violation of policemen the discipline and legality, misfeasance, professional deformation of policemen, cases of deviant and adictive behavior. To avoid these negative phenomena there should be the systems modernization, for instance professional and psychological assortment, professional development, training of specialists, policemen certification.

Nowadays realities show that agencies and departments of National police of Ukraine, as never before require highly qualified and competent leaders of different ranks.

According to the it. 5 art. 21 of Ukrainian Law «On National police» «...As a leader and deputies chief may be assigned a person that ${ }^{1}$ :

1) corresponds to general conditions of police service entrance,

2) has full high juridical education,

3) has length of work in law branch no less than seven years,

4) has experience in executive position no less than five years...».

However, as it is known, even corresponding to these items, a person can't fulfill successfully managerial functions. It is, first of all, connected with:

1. Assignment on leading position incompetent specialists. It causes the decline of the productivity of subordinate agencies activity

${ }^{1}$ Про Національну поліцію: Закон України від 02.07.2015 № 580-VIII. URL: https://zakon.rada.gov.ua/laws/card/580-19 (дата звернення 11.02.2019). 
and departments that in it`s turn influences on level of population`s confidence to police.

2. Imperfection of regulating the activity of the leaders of certain departments (subdepartments, offices, sectors) of National police. Thus, in National police there are some department (subdepartment, office, sector), that don't have precise regulation of their activity.

3. Imperfection of organizational and methodical provision of professional and psychological assortment of candidates for a managing position. Nowadays, in practice of professional and psychological assortment there are variety of test methods that are directed on candidates assortment for a managing position, by means of learning their professionally important qualities, style of leadership. Only learning the level of development all informative compound components of candidate competence varieties on managing position leaves outside the attention of specialists.

So, the goal of our research is to elaborate the general competency model of the leader of National police of Ukraine agencies. The tasks of research:

- learning and analysis of regulative acts, that provide the activity of National police of Ukraine, for separating general functions the leaders of National police of Ukraine;

- elaboration of general conceptual competence model the leader of National police of Ukraine on the grounds of separated functions of National police of Ukraine leaders;

- clarification the content of definition communicative competency, psychological competency, conflict competency, managerial competency, law competency, information and technological competency, economic competency, organization competency, strategy and prognostic competency, pedagogic competency, autopsychologic competency, general-culture competency, health-saving competency;

- carring out the questioning of leadership team of National police of Ukraine for expert estimation of necessary level of development the meaningful components of the leader's competence varieties;

- the substantiation of prospective directions of professionally psychological assortment of candidates on leadership job, improvement of professional skills and certification.

During the process of theoretical-applied scientific research there were used the complex of methods. Thus, with the use of general-logical 
(analysis, syntheses, induction, deduction, scientific abstraction, generalization, analogy, modelling, classification) and generaltheoretical (formalization, axiomatization, hypothetically-deductive) methods it was:

a) improved the content of principal definitions of competences variations;

b) classified the functions of leaders of National police of Ukraine;

c) developed general conceptual competence model of leader of National police of Ukraine;

d) developed a questionnaire for expert research the stage of progress for each of competence variation.

With the aid of questioning methods (survey, questionnaire) there was carried out the questionnaire of leadership team of National police of Ukraine to disclose the necessary stage of development the varieties of leader's competences.

By means of mathematic methods (calculation, registration, rank (-order) estimate) it was:

a) carried out the calculation of anonymous questioning of leaders of National police of Ukraine;

b) realized the indexes ranking. By the agency empiric methods (comparison, description) there were presented the principal results of scientific research.

This research was carried out on bases of Chief departments of National police of Ukraine in Odeska, Mikolaivska, Vinnitska, Hmelnitska, Chernivetska oblasts. The total quantity of participants is 437 leaders of different departments, (subdepartments, offices, sectors) of National police of Ukraine.

\section{The Results of Theoretical Research}

The strategic tasks of reformation the departmental education is renovation the content of education of higher education institutions with specific conditions of education of Ministry on internal affairs of Ukraine by means of it's approximation to the requirements of practical activity, creation the efficient mechanism of transformation the educational services from quantitative indexes to qualitative ones. It is precisely competence approach to the education that will provide the reformation of departmental education. 
«Competence approach» means directivity of educational process on forming and development of key (basic, principal) and subject competencies of personality. The result of such process will be the forming of general personal competence that is a collection of key competences, integrated characteristic of personality. Such characteristic must be formed during the process of education and contains knowledge, capabilities, attitude, the experience of activity and behavioral models of personality $^{2}$.

It is necessary to emphasize that the scientist of our country (I.A. Zimniaia, 2003, O.V. Ovcharuk, 2004, A.V. Hutorskiy, 2003, O.M. Tsilmak, 2011 etc.) and foreign ones (J.H. Holland, K.J. Holyoak, R.E. Nisbett, P.R. Thagard, 1986; R.S. Mansfield, 1996, L.M. Spencer, 1994, D.C. Rychen etc.) focused on the issue of personal competency.

The determination of competency as general ability, that is based on knowledge, experience, values, tendencies, acquired by means of education were devoted the scientific works of: A.L. Anreeva, N. Bratash, S. Bondar, E.V. Bondarevskaya, P.P. Borisova, B.A. Bolotova, G.Y. Voytko, V.V. Serikova, S.V. Kulkevicha etc. But, among these works there weren't scientific works, that concerned general competency model of the leader of National police of Ukraine.

It is necessary to accentuate that the scientists often use words «competency» and «competence» as synonyms in their works, although these terms have different meanings. In our opinion $\mathrm{a}^{3}: 1$ ) «competence»it is:

a) a range of authorities of any organization,

b) a range of functional authorities of a specialist;

2) «competency» - it is an ability of a person to fulfill certain activity successfully.

Competence is not a substantive scientific category, it`s determined by interdependent professionally important components such as: knowledge, abilities, skills, qualities, capabilities, motivation, world outlook and professionally-psychological readiness. The mentioned

${ }^{2}$ Компетентнісний підхід у сучасній освіті : світовий досвід та українські перспективи / заг. ред. Овчарук О.В. Київ: К.І.С., 2004. 112 с.

3 Цільмак О.М. Складові управлінської компетентності керівника органу досудового розслідування Національної поліції України. Юридична психологія. 2017. № 2 (21). C. 74-85. URL: http://elar.naiau.kiev.ua/jspui/bitstream/123456789/2805/ 1/2-1.pdf 
components is based on such evaluative component as the level of competency development (type, kind, subvariety). Competency is an integral and dynamic personal category, that depends on conditions and peculiarities of labor. That's why, with the change of methods, means and forms of professional activity the competency needs improvement.

The leader of a department (subdepartment, office, sector) of National police of Ukraine for inferiors is a key central figure that should be a model, mentor that leads, inspires on selfless labor and provides the raising of everyone's professionalism. The leader should not only fulfill professional functions successfully but to know perfectly the content of inferiors` professional activity.

The activity of leaders of bodies and departments of National police of Ukraine is based on some legal act - Constitution of Ukraine, The Law of Ukraine «On National police» and other laws, decrees of Verkhovna Rada of Ukraine and Cabinet of Ministers; orders of Ministry of internal affairs and National police etc. To determine what varieties of competency inherent in leader of one or another department (subdepartment, office, sector) of National police it is necessary to identify precisely what functions must he fulfill. Thus, to determine general conceptual competency model of the leader on National police of Ukraine we with the point of managerial functions analyzed legal acts, that are general for all policemen, including leaders. According to profound analysis of these norms, it was defined that the leaders of National police fulfill many different functions among which it is necessary to distinguish:

1) organizational function, that provides:

a) organization of the activity of subordinate department (subdepartment, office, sector) according to certain directions;

b) organization of interaction between departments (subdepartments, offices, sectors);

c) organization of cooperation between the workers of subordinate staff;

d) organization of commissions, work and expert group job;

e) organization of partner interrelation with a population;

f) organization of cooperation with a population etc.;

2) administrative function, that provides:

a) distribution of duties between inferiors;

b) giving a commission within authorities; 
c) making administrative decisions;

d) preparation and signing of orders, directions, regulations, assignments;

e) candidates assortment on a position etc.

3) control function, that provides a control for:

a) fulfilment of inferiors the requirements of legal acts, that regulate their activity;

b) fulfilment of inferiors certain tasks and assignments;

c) results of inferiors activity;

d) moral and psychological statue within the staff etc.

4) communicative function, that provides:

a) information exchange between Ministry of internal affairs of Ukraine and policeman;

b) information exchange between departments (subdepartments, offices, sectors);

c) information exchange between the workers of subordinate staff;

d) administration of subordinate department (subdepartment, office) by means of giving the orders, directions, regulations, assignments, recommendations;

e) process of the information acquisition from the subjects of defense and accusation; etc.;

f) current of professional conversation during citizens reception

5) motivational-objective function, that provides:

a) motivation of staff;

b) inferiors aiming to the effective result;

c) process of creation the system of conditions that guide the acts of inferiors in necessary direction for achieving a goal;

d) material and moral stimulation of inferiors by means of their incentive, or bringing to disciplinary responsibility etc.;

6) plan-prognostic function, that provides:

a) planning of the activity of subordinate department;

b) prediction of the possibility of certain risks;

c) raising of quality and efficiency of the activity of subordinate department (subdepartment, office, sector);

d) process of prediction the probable statue of an object, phenomenon, process for a certain moment of period of time (in past or future); 
e) creation the perspectives of development of subordinate department (subdepartment, office) etc.;

7) informational-analytical function that provides a collection, processing, generalization, systematization, analysis and evaluation of information to:

a) raise the efficiency and effectiveness of activity of subordinate department (subdepartment, office);

b) planning of subordinate department (subdepartment, office) activity;

c) make the administrative decisions;

d) prevent the negative consequences etc.

8) prophylactic function, that provides:

a) prevention of loses among the staff;

b) suicides prophylaxis among the inferiors;

c) prophylaxis of aditive addiction;

d) prophylaxis of destructive onset;

e) corruption prevention;

f) prevention the conflict interrelation between inferiors and the subject of professional activity etc.;

9) technological function, that provides:

a) a) modernization of professional activity;

b) upgrading of technical means and methods;

c) renovation of software etc.;

10) economical function, that provides:

a) objective learning of material resources;

b) frugal attitude to material-technical equipment;

c) saving material resources etc.;

According to the content of the norms of legal acts, that regulate the activity of National police and also on the grounds of distinguished functions of the leader we consider necessary to prove general conceptual competency model of the leader of department (subdepartment, office, sector) of National police. It is necessary to denote that managerial activity of the leader is directed to:

a) activity (that is it concerns planning, organization and assuring of professional activity);

b) society (that is it may concern inferiors, subjects of professional activity, citizens, workers of other departments (subdepartments, offices, sectors); 
c) oneself (that is setting on result of managerial activity, control of own emotions, statues, processes etc.).

So, to manage a staff psychologically correctly, rationally, productively, effectively and successfully the leader of the department (subdepartment, office, sector) should develop such varieties of competency as:

\section{Social direction:}

1) communicative competency (the ability of a person to realize communicative interaction, to establish and support necessary contacts with other people ${ }^{4}$ ) - comprises communicative and administrative functions;

2) psychological competency (the ability of a person psychologically correctly, rationally, productively and effectively administrate, taking into consideration all psychological peculiarities and qualities ) - comprises all above-mentioned functions.

3) conflict competency (the ability of a person to solve the interindividual conflicts rationally, productively, and effectively) comprises organizational, administrative, prophylactic, communicative, planning-prognostic, motivation-objective, controlling, informationalanalytic functions.

\section{Activity direction:}

1) managerial competency (the ability of a person psychologically correctly, rationally, productively and effectively fulfill managerial activity) - comprises planning-prognostic, organizational, controlling functions;

2) legal competency (the ability of a person to the legal behavior and activity, that is to identify during the process of vital activity the legal awareness and not to break the prescriptions of legal acts) comprises all above-mentioned functions;

3) informational-technological competency (the ability of a person to apply and use modern innovative technologies ${ }^{5}$ ) - comprises planning-prognostic, organizational, informational-analytic, technological, economical functions;

${ }^{4}$ Цільмак О.М. Професіогенез компетентності фахівців кримінальної міліції: теорія та практика : монографія. Одеса: РВВ ОДУВС, 2011. 432 с.

${ }^{5}$ Там само. 
4) economical competency (the ability of a person to orientate in new market's conditions, to adapt effectively to them and apply economical methods of management) - comprises all above-mentioned functions;

5) organizational competency (the ability of a person to organize his own professional activity and the activity of inferiors) - comprises organizational, managerial, communicative, planning-prognostic, motivation-objective, controlling functions;

6) strategic-prognostic competency (the ability of a person to determine the priority directions of development of subordinate staff for achievement supplied goals, to predict probable perspectives and possible risks) - comprises all above-mentioned functions;

7) pedagogic competency (the ability of a person to teach and educate inferiors rationally, productively and effectively) - comprises all above-mentioned functions.

\section{Personal direction:}

1) autopsychologic competency (it is an ability to cognate oneself, one`s image «I $»)$, by means of self-observation, self-diagnosis, adequate self-assessment, and self-consciousness ${ }^{6}$ ) - comprises motivationobjective, psychological, prophylactic, informational-analytic functions. It is necessary to distinguish such subtypes of autopsychologic competency ${ }^{7}$ :

* intrapsychologic (lat. «intra»-in+gr. «psyche»-soul) - it is an ability of a person to understand himself;

* intraperceptive (lat «intra» - in+lat. «perception»-imagination, reception) - it is an ability to understand one`s adequate;

2) general-culture competency (an ability of a person to keep certain generally accepted rules of behavior culture) - comprises motivation-objective, psychological, prophylactic, informationalanalytic, communicative functions;

3) health-saving competency (an ability of a person to keep the fundaments of healthy lifestyle and rules of safe behavior in all areas of vital activity) comprises motivation-objective, psychological, prophylactic, informational-analytic functions.

${ }^{6}$ Цільмак О.М. Професіогенез компетентності фахівців кримінальної міліції: теорія та практика : монографія. Одеса: РВВ ОДУВС, 2011. 432 с.

${ }^{7}$ Ibidem. 
Thus, general conceptual competency model of the reader of department (subdepartment, office, sector) of National police includes three interrelated principal types of competences (personal, social and activity), that are determined by certain kinds:

1) activity - managerial, legal, informational-technological, economical, organizational, strategic-prognostic, pedagogical;

2) social - communicative, psychological, conflict;

3) personal - autopsychologic (intrapsychologic and intraperceptive) general-culture, health-saving.

Every of these varieties of competency of the leader of department (subdepartment, office, sector) of National police determines interrelated and interdependent professionally important components: knowledge, abilities, skills, habits, qualities, capabilities, motivation, world outlook and professionally-psychological readiness. To determine the range of development different varieties of leader's competency it is necessary to estimate the level of development it's containing compound components.

Containing compound components of mentioned-above varieties of competency of the leader that or other department (subdepartment, office, sector) of National police must become criteria for professionally-psychological assortment and certification.

So, the verification of constructed general competency model of the leader of National police by means of it's expert evaluation of containing compound components is very relevant.

\section{The Results of Empiric Research}

According to the proved general conceptual competence model of the leader of National police, there were determined main containing compound components of the competency of this model, a questionnaire was created and a questioning of 437 leaders of different departments, subdepartments, offices on National police of Ukraine was carried out.

It was proposed to the respondents - to realize the expert estimation about necessary level of development the containing compound component of competency varieties (high, medium, low), that are necessary for successful managerial activity of the leader of National police.

As a result of total expert estimations the containing compound components that or other variety of competency we calculated it's average indexes and determined standard general competence profile of the leader of National police. So in respondent`s point of view: 
1) communicative competency should have high level of development $-92 \%$ respondents pointed like that (401 persons);

2) psychological competency should have high level of development $-96 \%$ respondents pointed like that (419 persons);

3) conflict competency should have high level of development $98 \%$ respondents pointed like that (430 persons);

4) managerial competency should have high level of development $100 \%$ respondents pointed like that (437 persons);

5) legal competency should have high level of development $100 \%$ respondents pointed like that (437 persons);

6) informational-technological competency should have high level of development $-91 \%$ respondents pointed like that (397 persons);

7) economical competency should have medium level of development $-68 \%$ respondents pointed like that (297 persons);

8) organizational competency should have high level of development $-100 \%$ respondents pointed like that (437 persons);

9) strategic-prognostic competency should have high level of development $-94 \%$ respondents pointed like that (412 persons);

10)pedagogical competency should have medium level of development $-81 \%$ respondents pointed like that (354 persons);

11)autopsychologic competency should have high level of development $-81 \%$ respondents pointed like that (353 persons);

12) general-cultural competency should have high level of development $-88 \%$ respondents pointed like that (386 persons);

13) life-saving competency should have medium level of development $-86 \%$ respondents pointed like that (376 persons).

Thus, in respondents point of view in the leaders of National police all varieties of competences should have high level of development, beside economical, health-saving and pedagogical these ones should have medium level of development.

Mentioned-above general competency profile of the leader of National police is standard. The research that was carried out proved the general conceptual competency model of the leader of National police, that was created by us based on distinguished functions from legal acts.

However, the model that was mentioned above is experimental and standard, based on which and according to which - it is necessary to:

1. Concretize the content of professionally important components (knowledge, abilities, skills, habits, qualities, capabilities, motivation, 
world outlook and professionally-psychological readiness) of all varieties of the leader`s competencies of certain department (subdepartment, office, sector) according to the requirements of legal acts, that regulate the activity of National police.

2. Provide the questionnaires for expert evaluation of necessary level of development of containing compound components of competences varieties in the leader of certain department (subdepartment, office, sector).

3. Carry out the questioning of the leaders of certain department (subdepartment, office, sector) of National police of Ukraine.

4. Handle the questionnaires by means of mathematical statistic methods. Take into consideration general average indexes of necessary level of development:

1) knowledge, abilities, skills, habits, qualities, capabilities, motivation, world outlook and professionally-psychological readiness of each variety of the leader's competency; and also

2) every variety of leader's competency.

5. Construct competency profile of the leader of certain department (subdepartment, office, sector), that will become a standard for professionally-psychological assortment of candidates on leading position.

6. Create «Card of leader's competence profile» of certain departments (subdepartments, offices, sectors) and implement it in personnel departments of National police.

\section{Discussion of Results}

Thus, general conceptual competence model of the leader of the department of National police was proposed by us for the first time. The results of carried out research proved our hypothesis about managerial competency of the leader ${ }^{8}$.

It is necessary to mention, that to implement the competency approach in the system of Ministry of internal affairs there must be a reorientation on personal-social-activity competence approach processes of:

8 Цільмак О.М. Складові управлінської компетентності керівника органу досудового розслідування Національної поліції України. Юридична психологія. 2017. № 2 (21). C. 74-85. URL: http://elar.naiau.kiev.ua/jspui/bitstream/123456789/2805/1/ 2-1.pdf 
1) advance training of policemen;

2) policemen certification;

3) professionally-psychological assortment of;

a) the candidates police service;

b) the candidates on policemen position;

c) the candidates on study in higher education institutions with specified conditions of education of Ministry of internal affairs of Ukraine;

d) policemen - the candidates for transition or career promotion;

e) policemen - candidates on leading position etc.;

4) cadets and listeners training in higher education institutions with specified conditions of education of Ministry of internal affairs of Ukraine.

It is necessary to emphasize, that proper professionally important level of leader`s competency one or another department (subdepartment, office, sector) of National police is a guarantee of successful professional activity a subordinate staff. That's why the processes of training, advance training, professionally-psychological assortment and certification of candidates on leading position and the leaders of certain departments (subdepartments, offices, sectors) of National police should be reoriented into personal-social-activity competency approach.

The processes of training, professional development, professionallypsychological assortment and certification of policemen of certain departments (subdepartments, offices, sectors) of National police have certain goal. So, the goal of the training of policemen, the candidates on leading position of certain departments (subdepartments, offices, sectors) of National police is the development and forming of their containing compound components of the competencies varieties, by means of complex learning the necessary knowledge, skills, and abilities and also the methods, means and forms of practical activity.

The result of the training must be - the formed ability and professionally-psychological readiness of the person to the successful managerial activity.

The goal of the professional development of the leader of certain departments (subdepartments, offices, sectors) of National police - is the improvement of certain varieties of competences (that don't have enough level of development). 
The result of the professional development must be - the correspondence of the level of development of the containing compound components of the competencies varieties to their standard.

The goal of the professionally - psychological assortment of the policemen, the candidates on the leading position of certain department (subdepartment, office, sector) of National police is a determination of the level of development of professionally important varieties of competences.

The result of the professionally - psychological assortment of the candidates on the leading position must be - a assortment on leading position the most effective, successful, competitive and competent specialists.

During the process of - psychological assortment of the candidates on the leading position, - to study the level of development of all containing compound components of the competencies varieties of the candidates on the position of the leader of certain department (subdepartment, office, sector). The results of estimation that were received should be brought in «Card of leader"s competency profile».

Thus, for example, for expert evaluation of the degree of knowledge of the candidate - it is possible to provide the verification of his degree of knowledge by means of tests, and situational tasks. The abilities, skills, qualities, capabilities, motivation, world outlook and professionally-psychological readiness should be checked and estimated during the fulfillment the certain instructions and tasks by the candidates. Professionally important qualities of the candidate on the leading position should be determined by means of the battery of psychodiagnostic methods and observation.

For making a decision about appointment it is necessary to compare competency profile of the candidate with a standard competency profile of the leader of certain department (subdepartment, office, sector). Thus, if a person, for example, has insufficient level of formation certain knowledge or abilities, but his candidacy is the most acceptable for appointment, that person should be directed to the professional development courses. On professional development courses the candidate should be provided with deficient knowledge and abilities. After passing the courses the level of forming in candidates one or that containing compound components of the competencies varieties should be checked and previous and current marks should be compared. 
According to the results of repeated learning the final decision about appointment of the candidate on the leading position should be made.

It is offered to carry out the psychological and pedagogic maintenance of the junior leaders activity (no less than one year). If necessary, they should be directed to the professional development courses (no often than once a year).

The goal of the leader's certification of the certain department (subdepartment, office, sector) of National police is the determination the level of professionally-psychological correspondence of the leader to the current position.

The results of leaders` certification must be a decision about:

a) promotion (demotion) in qualification category of the leader;

b) promotion the qualification of the leader;

c) promotion (demotion) of the official rate of pay;

d) leader`s award;

e) transition to the other equivalent position with less job content etc.

In the USA the interval between leaders` certification is one year. It is necessary to denote, that to take vacant position - the leader of certain department (subdepartment, office, sector) of National police there should be announced a vacancy of carried out a certification. During these processes the level of «professional competency, personal qualities and achievements of the candidates...» are taken into consideration (it. 2., ar.. $52^{9}$ ).

«...To provide transparent assortment (announcement a vacancy) and promotion the policemen on the grounds of objective evaluation of professional level and personal qualities of each policeman, their correspondence to the position, determination the perspective of service usage in police agencies the constant police commissions are established...» (it. 1 , ar.. $51^{10}$ ). Only the evaluation of professional level provides the learning of the level of the policeman`s competency.

Henceforth, the implementation of competency approach in the system of the Ministry of internal affairs of Ukraine will provide the growth the level of the professionalism and professional craftsmanship

9 Про Національну поліцію: Закон України від 02.07.2015 № 580-VIII. URL: https://zakon.rada.gov.ua/laws/card/580-19 (дата звернення 11.02.2019).

${ }^{10}$ Ibidem. 
of policemen, and will make a provision the successfulness and the quality of the professional activity and gradually will increase the level of belief of the population to the police.

\section{CONCLUSIONS}

1. On the basis of the analysis of the legal acts that regulate the activity of the National police of Ukraine, there were distinguished general functions of the leaders (organizational, administrative, prophylactic, communicative, planning-prognostic, motivation-objective, controlling, informational-analytic, technological, economical). Based on distinguished general functions there was created the standard general conceptual competence model of the leader on National police of Ukraine.

2. General conceptual competency model of the leader on National police of Ukraine comprises three interrelated key types of competency personal, social and activity, that are determined and provided by the communicative, psychological, conflict competences; activity - by the managerial, legal, informational-technological, economical, organizational, strategic-prognostic, pedagogical; and personal - by authopsychologic (intrapsychologic and intraperceptive), general-culture and health-saving.

3. For better understanding the essence of the competences varieties (communicative, psychological, conflict, managerial, legal, informational-technological, economical, organizational, strategicprognostic, pedagogical, authopsychologic, general-culture and healthsaving we specified their interpretation.

4. Having based on the questioning of the managerial personnel of National police of Ukraine, there were established the necessary level of development of the leader's on National police competence varieties. It was determined that in the leaders all of the competence varieties should have the high level of development, besides economical, healthsaving and pedagogical - they should have the medium level of development. It was mentioned, that during candidate's assortment on the leading position it is necessary to take into consideration not only the principal style of management and availability the leader qualities in the candidate on the leading position, but the level of development the competences varieties.

5. It was emphasized, that nowadays it is very relevant and important to: 
a) work out and prove the conceptual and competency models of the leaders of certain departments (subdepartments, offices, sectors) of National police of Ukraine;

b) determine substantially the containing compound components (knowledge, abilities, skills, qualities, capabilities, motivation, world outlook and professionally-psychological readiness for managerial activity) of the competency varieties according to the requirements of legal acts, that regulate the activity of the leader one or another department (subdepartment, office, sector) and those functions, that are assigned to him;

c) provide an expert estimation of the necessary level of development of containing compound components of competency varieties;

d) construct of standard competency profiles of the leaders one or another department (subdepartment, office, sector);

e) design «Card of leader`s competency profile».

\section{SUMMARY}

Agencies and departments of National police of Ukraine, as never requires highly qualified, competitive, and competent managerial staff. On the basis of the analysis of the legal acts that regulate the activity of the National police of Ukraine, there were distinguished general functions of the leaders (organizational, administrative, prophylactic, communicative, planning-prognostic, motivation-objective, controlling, informational-analytic, technological, economical). Based on distinguished general functions there was created the standard general conceptual competence model of the leader on National police of Ukraine. General conceptual competency model of the leader on National police of Ukraine comprises three interrelated key types of competency - personal, social and activity, that are determined and provided by the communicative, psychological, conflict competences; activity - by the managerial, legal, informational-technological, economical, organizational, strategic-prognostic, pedagogical; and personal - by authopsychologic (intrapsychologic and intraperceptive), general-culture and health-saving.

For better understanding the essence of the competences'varieties (communicative, psychological, conflict, managerial, legal, informationaltechnological, economical, organizational, strategic-prognostic, 
pedagogical, authopsychologic, general-culture and health-saving we specified their interpretation.

Having based on the questioning of the managerial personnel of National police of Ukraine, there were established the necessary level of development of the leader's on National police competence varieties. It was determined that in the leaders all of the competence varieties should have the high level of development, besides economical, health-saving and pedagogical - they should have the medium level of development. It was mentioned, that during candidate's assortment on the leading position it is necessary to take into consideration not only the principal style of management and availability the leader qualities in the candidate on the leading position, but the level of development the competences varieties.

\section{REFERENCES}

1. Компетентнісний підхід у сучасній освіті: світовий досвід та українські перспективи / заг. ред. Овчарук О. В.. Київ: К.І.С, 2004. 112 c.

2. Про вищу освіту: Закон України від 01.07.2014 № 1556-VII. URL: https://zakon.rada.gov.ua/laws/show/1556-18 (дата звернення 11.02.2019).

3. Про Національну поліцію : Закон України від 02.07.2015 № 580-VIII. URL: https://zakon.rada.gov.ua/laws/card/580-19 (дата звернення 11.02.2019).

4. Цільмак О.М. Професіогенез компетентності фахівців кримінальної міліції: теорія та практика : монографія. Одеса: РВВ ОДУВС, 2011. $432 \mathrm{c.}$

5. Цільмак О.М. Складові управлінської компетентності керівника органу досудового розслідування Національної поліції України. Юридична психологія. 2017. № 2 (21). C. 74-85. URL: http://elar.naiau.kiev.ua/jspui/bitstream/123456789/2805/1/2-1.pdf

Information about the author: Tsilmak O. M.

Doctor of Legal Sciences, Professor, Professor at the Department of Criminalistics,

Forensic Medicine and Psychiatry, Odesa State University of Internal Affairs 17, Armiys'ka str., Odesa, 65058, Ukraine 